\title{
BANKING WITH A CHATBOT - A STUDY ON TECHNOLOGY ACCEPTANCE
}

\author{
Mónika-Anetta ALT* \\ Babeş-Bolyai University, Romania \\ Ibolya VIZELI \\ Babeş-Bolyai University, Romania \\ Zsuzsa SĂPLĂCAN \\ Babeş-Bolyai University, Romania
}

\begin{abstract}
The implementation of chatbot technology is evolving rapidly in the banking industry, yet customer acceptance is behind. The aim of the present paper is to identify the factors that influence consumers' intention to use chatbot technology applied in the banking industry. The measurement development and hypotheses were based on the technology acceptance model extended with compatibility, customers' perceived privacy risk and awareness of the service. The sample contains 287 respondents, out of whom $24 \%$ have previously used a banking chatbot. The measure items were validated by a measurement model and hypotheses were tested using Partial Least Squares-Structural Equation Modeling (PLS-SEM). The findings highlight the importance of perceived compatibility and perceived usefulness in the adoption of banking chatbot technology. Awareness of the service has an effect on perceived ease of use, perceived privacy risk, and it indirectly affects usage intention of banking chatbots through perceived usefulness. Also, perceived ease of use influences perceived usefulness, and perceived compatibility has an effect on both perceived ease of use and perceived usefulness. Perceived ease of use and perceived privacy risk show no effect on usage intention.
\end{abstract}

Keywords: Technology acceptance model, Artificial Intelligence, Chatbot, Self-service, Banking, Partial Least Squares-Structural Equation Modeling (PLS-SEM)

JEL classification: M31, O33.

\footnotetext{
* Corresponding author. Address: Babeş-Bolyai University; 400591 Cluj-Napoca, Str. Teodor Mihali 58-60, Romania. Tel: +40 2644186 52, Email: monika.alt@econ.ubbcluj.ro
} 


\section{Introduction}

Recent technological developments have transformed the way consumers and financial institutions interact with each other (Shaikh and Karjaluoto, 2015). Moreover, the COVID-19 pandemic has led to rapid shift to digital technologies and banks have transitioned to remote sales and provision at a fast pace (McKinsey, 2020). The rise of artificial intelligence (Al) based technology is contributing extensively to this transformation as more and more banks have begun to implement Al-based applications with the aim of deepening customer relationships, providing more personalized offers, detecting and preventing fraud, improving processes for anti-money laundering, and cost saving (Business Insider, 2021). One very popular and impactful form of technological development in the financial sector is the implementation of the Al-based chatbot technology (Richad et al., 2019).

Chatbot technology is a system based on Al that communicates with users and performs basic tasks through chat or speech interfaces (Nguyen and Sidorova, 2017). According to forecast, the chatbot market size is projected to reach 102.29 billion USD by 2025 (Mordor Intelligence, 2019), and the success rate of bot interactions (queries completed without the interference of a human operator) in the banking sector is expected to be over 90\% by 2022 (Juniper Research, 2020). Yet, in order for both banks and consumers to exploit from the advantages of the banking chatbot technology, it is important to examine the drivers of consumers' willingness to adopt this technology.

The adoption of innovations applied in the banking industry, such as i-banking and $\mathrm{m}$-banking, is widely studied in the literature. Although the above mentioned studies provide essential contribution to technology adoption in the context of the banking industry, there is limited knowledge on the acceptance of banking chatbots. There are already a few studies that highlighted the importance of studying chatbot acceptance in the context of the banking industry, but only one has conducted a research related to the technology acceptance model (Richad et al., 2019), and one is related to the customer experience for consumers who are banking with chatbot technology (Trivedi, 2019). In order to extend the knowledge regarding chatbot acceptance in banking, the present study aims to investigate the determinants of chatbot adoption in the banking industry, based on technology adoption literature in the banking industry.

The aim of the current study is to identify those factors that have an influence on consumers' intention to use chatbot technology applied in the banking industry. A special adoption model was developed for banking chatbots, extending the TAM model. Data is collected through an online, self-administrated questionnaire and the conceptual model is examined using the PLS-SEM method.

The structure of the paper is as follows. First, in the Literature review section, earlier research findings on banking technology adoption (e.g. i-banking and mbanking) are presented, and the chatbot technology and research on its adoption in the banking industry are described. Next, in the Conceptual framework development section, the research model is conceptualized and hypotheses are formulated. In the Research method section, the sample and measures are described. Thereafter, in the Data analysis section, the data and methods used in this study are presented. 
Finally, the results are discussed, including the implications for theory and practice, limitations of the study and further possible research directions are outlined, and conclusions are drawn.

\section{Literature review}

\subsection{Banking technologies' adoption by customers}

The banking industry has been profoundly influenced by technological evolution in recent decades and consumer adoption of banking technologies is a widely researched topic in the literature. Thus, a more in-depth look into the processes behind the adoption of banking chatbots can be gained through the review of the existing literature on the adoption of other technologies applied in the banking sector, such as i-banking and m-banking.

Several theories have been implemented in order to analyze the adoption of different IT systems. According to Hanafizadeh and Khedmatgozar (2012), the most influential theoretical models applied in i-banking adoption studies, are the Diffusion of innovation theory (DIT), the Technology acceptance model (TAM), the Decomposed theory of planned behavior (DTPB), the Extended technology acceptance model (TAM2) and the Unified theory of user acceptance of technology (UTAUT), the latter becoming dominant in the literature in recent years. Shaikh and Karjaluoto (2015) analyzed and synthesized existing studies of m-banking adoption and concluded that the most frequently used adoption models were TAM, followed by DIT and UTAUT, while several studies applied a combination of different technology acceptance models (e.g. TAM and DIT).Several of the above mentioned models are composed of intention to use or actual usage as the dependent variables. Consequently, the key dependent variables in the i-banking adoption literature (Yousafzai, 2012) are behavioral intention to use and actual usage of the technology, while in m-banking adoption, besides the two earlier mentioned dependents, attitude is also adopted in order to analyze technology acceptance (Shaikh and Karjaluoto, 2015).

Based on the literature review, it could be concluded that usefulness and ease of use are fundamental variables in studying technology acceptance in the banking sector. It should also be highlighted that compatibility was found as a key determinant for m-banking (Koenig-Lewis et al., 2010; Shankar and Kumari, 2016; Giovanis et al., 2019) and i-banking (Giovanis et al., 2012) adoption. Therefore, it is expected that compatibility will influence banking chatbot adoption as well. However, technology acceptance could be inhibited directly or indirectly (Moldovan and Săplăcan, 2018) by several factors, such as different types of risk factors. In some cases, perceived privacy risk was found to be a barrier for m-banking (Arif et al., 2016; Shankar and Kumari, 2016) and i-banking (A. N. Giovanis et al., 2012) adoption. Supposedly, perceived privacy risk will be a barrier in adopting banking chatbot as well.

\subsection{Chatbot technology: description and previous research}

A chatbot application is a computer program that mimics human conversations in its natural format, including text or spoken language, using artificial intelligence techniques, such as Natural Language Processing (NLP), image and video processing and audio analysis (Bala et al., 2017). 
Chatbot applications offer benefits for both companies and consumers. First, chatbots enable consumers to get in touch with companies anytime from anywhere using their own mobile devices, thus they can get quick and relevant responses to their questions. Second, the implementation of these applications allows companies to target consumers in a more direct and personal way, and companies can save on personnel costs in the area of customer services. In addition to the benefits of the technology, the usage of chatbots may also involve several risk factors, including issues regarding data security and financial risks (Vieira and Sehgal, 2017; Richad et al., 2019).

Recently published scientific papers analyzed the adoption of chatbot technology in the tourism industry (Melián-González et al., 2021), in the health care industry (Laumer et al., 2020), and in the field of higher education (Almahri et al., 2020). Regarding the adoption of chatbots applied in the financial industry, only a few studies examined the acceptance of these applications in the context of the insurance sector (Cardona et al., 2019) and the banking sector (Gupta and Sharma, 2019; Quah and Chua, 2019; Trivedi, 2019, Richad et al., 2019; Sarbabidya and Saha, 2020). Although several studies have examined the factors influencing the acceptance of chatbots, the findings carried out in different fields may not be transferable for financial services (Cardona et al., 2019). Specific research is required in case of banking.

\subsection{Chatbot technology in the banking industry}

Chatbots applied in the financial industry can assist customers in managing financial transaction such as reviewing an account, reporting lost cards or making payments, renewing a policy or handling a refund (Tarbal, 2020). In the literature, there are several recently published studies that focused on chatbot technology applied in the financial industry (Cardona et al., 2019; Gupta and Sharma, 2019; Quah and Chua, 2019; Richad et al., 2019; Trivedi, 2019; Sarbabidya and Saha, 2020) (Table 1).

Cardona et al. (2019) studied the adoption and diffusion of chatbots in the context of insurance, concluding that the majority of the participant were familiar with the technology and would prefer to use it at the beginning of the advisory process, while one third of the participants rejected the adoption of chatbots. Gupta and Sharma (2019) examined the customers' attitude towards chatbots in the banking industry and the findings of the study revealed positive correlation between the positive attitude for chatbots and their utility, accessibility and threats. Quah and Chua (2019) explored the effectiveness of the use of chatbot technology in Singapore's banking industry and investigated chatbot functionality to determine if it would meet customer expectations. They found that detailed information provided by the banking chatbot was the most important factor for consumers, followed by fast response, functionality, interactivity, ease of use and data privacy and protection. It was also found that some of the users were not satisfied with the banking chatbot because it didn't provide an immediate answer when needed. Richad et al. (2019) investigated the acceptance factors of chatbot technology in the banking industry in Indonesia in case of Millennials based on TAM, and found that innovativeness, perceived usefulness, perceived ease of use and attitude towards using the chatbot had significant effect on behavioral 
intention. Trivedi (2019) examined customer experience of using banking chatbots and its impact on brand love adopting the Information Systems (IS) success model among. The results showed that system quality, information quality and service quality had significant impact on customer experience, system quality being the strongest predictor. Perceived risk reduced the impact of the three quality dimensions on customer experience, and customer experience of using the chatbot led to love for the brand that provided the technology. Sarbabidya and Saha (2020) found that the role of chatbots in customer service of the banking industry was positively affected by advisory services, ease of use and convenient service, cost effective and efficient service, customer-friendly service, customized service, relationship banking services, responsive service, trustworthy service, value-based useful service and maintaining customers security and privacy.

Table 1: Summary of studies regarding banking chatbots

\begin{tabular}{|c|c|c|c|c|}
\hline Authors & $\begin{array}{l}\text { The aim of } \\
\text { the study }\end{array}$ & Theories/Studied variables & $\begin{array}{c}\text { Research method/ } \\
\text { sample }\end{array}$ & $\begin{array}{c}\text { Data } \\
\text { analysis }\end{array}$ \\
\hline $\begin{array}{l}\text { (Cardona et } \\
\text { al., 2019) }\end{array}$ & $\begin{array}{l}\text { Adoption and } \\
\text { diffusion of } \\
\text { chatbots in the } \\
\text { German } \\
\text { insurance } \\
\text { sector }\end{array}$ & $\begin{array}{l}\text { DOI: relative advantages, compatibility, } \\
\text { complexity, trialability, observability } \\
\text { TOE: top management support, IS } \\
\text { infrastructure, costs, environmental } \\
\text { threats, competitive pressure, } \\
\text { collaborative networks } \\
\text { TAM: perceived usefulness, perceived } \\
\text { ease of use, perceived behavioral } \\
\text { control }\end{array}$ & $\begin{array}{l}\text { Qualitative, } \\
\text { quantitative } \\
\text { Semi-Structured } \\
\text { Expert Interviews, } \\
\mathrm{N}=7 \\
\text { Web-based cross } \\
\text { sectional survey, } \\
\mathrm{N}=300 \\
\text { Data collected in } \\
\text { Germany in } 2018\end{array}$ & Descriptive \\
\hline $\begin{array}{l}\text { (Gupta and } \\
\text { Sharma, } \\
\text { 2019) }\end{array}$ & $\begin{array}{l}\text { Analysis of } \\
\text { customers' } \\
\text { attitude } \\
\text { towards the } \\
\text { chatbots in } \\
\text { banking } \\
\text { industry of } \\
\text { India }\end{array}$ & $\begin{array}{l}\text { attitude } \\
\text { observed utility (ease of use, ease of } \\
\text { process, engagement with customer } \\
\text { service) } \\
\text { observed accessibility (easy for basic } \\
\text { transactions, speedy process, user } \\
\text { friendliness) } \\
\text { observed threat and awareness (data } \\
\text { security and privacy, social awareness, } \\
\text { friends and family using it) }\end{array}$ & $\begin{array}{l}\text { Quantitative } \\
\text { Data collected via } \\
\text { Facebook and } \\
\text { WhatsApp, N=72 } \\
\text { Data collected in } \\
\text { India in } 2019\end{array}$ & $\begin{array}{l}\text { Bivariate } \\
\text { analysis }\end{array}$ \\
\hline $\begin{array}{l}\text { (Quah and } \\
\text { Chua, } \\
\text { 2019) }\end{array}$ & $\begin{array}{l}\text { Analysis of the } \\
\text { effectiveness } \\
\text { of the current } \\
\text { use of chatbots } \\
\text { in Singapore's } \\
\text { banking } \\
\text { industry }\end{array}$ & $\begin{array}{l}\text { user experience: response rate, } \\
\text { functionality and usability } \\
\text { satisfaction: interactivity, informative, } \\
\text { data privacy and protection }\end{array}$ & $\begin{array}{l}\text { Quantitative, } \\
\text { qualitative } \\
\text { Interviews } \\
\text { Qualitative user } \\
\text { tests }\end{array}$ & Descriptive \\
\hline $\begin{array}{l}\text { (Richad et } \\
\text { al., 2019) }\end{array}$ & $\begin{array}{l}\text { Analysis of the } \\
\text { factors that } \\
\text { influence } \\
\text { millennial's } \\
\text { technology } \\
\text { acceptance of } \\
\text { chatbots in the } \\
\text { banking } \\
\text { industry in } \\
\text { Indonesia }\end{array}$ & $\begin{array}{l}\text { TAM } \\
\text { attitude towards usage, behavioral } \\
\text { intention } \\
\text { innovativeness, perceived usefulness, } \\
\text { perceived ease of use }\end{array}$ & $\begin{array}{l}\text { Quantitative } \\
\text { Simple random } \\
\text { sampling technique, } \\
\mathrm{N}=400 \\
\text { Data collected in } \\
\text { Indonesia in } 2018\end{array}$ & SEM \\
\hline
\end{tabular}




\begin{tabular}{|c|c|c|c|c|}
\hline Authors & $\begin{array}{l}\text { The aim of } \\
\text { the study }\end{array}$ & Theories/Studied variables & $\begin{array}{c}\text { Research method/ } \\
\text { sample }\end{array}$ & $\begin{array}{c}\text { Data } \\
\text { analysis }\end{array}$ \\
\hline $\begin{array}{l}\text { (Trivedi, } \\
\text { 2019) }\end{array}$ & $\begin{array}{l}\text { Examination of } \\
\text { customer } \\
\text { experience of } \\
\text { using banking } \\
\text { chatbots and } \\
\text { its impact on } \\
\text { brand love in } \\
\text { India }\end{array}$ & $\begin{array}{l}\text { Information Systems (IS) success model } \\
\text { customer experience, brand love } \\
\text { system quality, information quality, } \\
\text { service quality, perceived risk }\end{array}$ & $\begin{array}{l}\text { Quantitative } \\
\text { Online } \\
\text { questionnaire sent } \\
\text { to Gen } \mathrm{Z} \\
\text { individuals, } \mathrm{N}=258 \\
\text { Data collected in } \\
\text { India in } 2018\end{array}$ & SEM \\
\hline $\begin{array}{l}\text { (Sarbabidy } \\
\text { a and } \\
\text { Saha, } \\
2020)\end{array}$ & $\begin{array}{l}\text { Examination of } \\
\text { the role of } \\
\text { chatbots in } \\
\text { customer } \\
\text { service of the } \\
\text { banking } \\
\text { industry of } \\
\text { Bangladesh }\end{array}$ & $\begin{array}{l}\text { customer service } \\
\text { advisory services, ease of use and } \\
\text { convenient service, cost effective and } \\
\text { efficient service, customer-friendly } \\
\text { service, customized service, relationship } \\
\text { banking services, responsive service, } \\
\text { trustworthy service, value based } \\
\text { usefulness, security and privacy }\end{array}$ & $\begin{array}{l}\text { Quantitative } \\
\text { Judgment sampling } \\
\text { method, N=125 } \\
\text { Data collected in } \\
\text { Bangladesh in } 2019\end{array}$ & Regression \\
\hline
\end{tabular}

Based on the reviewed literature regarding the adoption of chatbots applied in the banking industry, it can be concluded that this topic is in the early phase of research, mostly based on descriptive analysis (Table 1). Only one study (Richad et al., 2019) analysed chatbot acceptance based on theoretical models and analysed a conceptual model in order to identify the factors that have significant impact on adoption. Thus, the present study aims to fill this research gap by building a conceptual model of technology acceptance based on previous studies related to chatbots used in financial services (Cardona et al., 2019; Richad et al., 2019), and other technologies' acceptance in the financial sector (e.g. m-banking, i-banking).

\section{Conceptual framework development}

The aim of the paper is to identify those factors that have an influence on consumers' intention to use chatbot technology applied in the banking industry. Therefore, the proposed research model is based on technology acceptance (Davis' TAM, Venkatesh's UTAUT) in the context of the financial services. In order to provide a simple conceptual model, only those variables were included into the model, which were found to be relevant for different banking technologies' adoption. It is generally accepted that perceived usefulness (known as performance expectancy in Venkatesh's UTAUT) and perceived ease of use (known as effort expectancy in Venkatesh's UTAUT) are key determinants in financial technologies' acceptance and for banking chatbots as well (Richad et al., 2019). The basic TAM model will be extended with one more driver, namely with compatibility and one barrier, namely privacy risk. When introducing new services, banks tend to inform their customers as part of a communication campaign. Therefore, customers' awareness of the new technology is an important antecedent of technology acceptance. Knowledge about chatbot technology was examined in the context of insurance companies (Cardona et al., 2019). Figure 1 illustrates the proposed research model. 
Figure 1: Proposed research model for intention to use banking chatbots

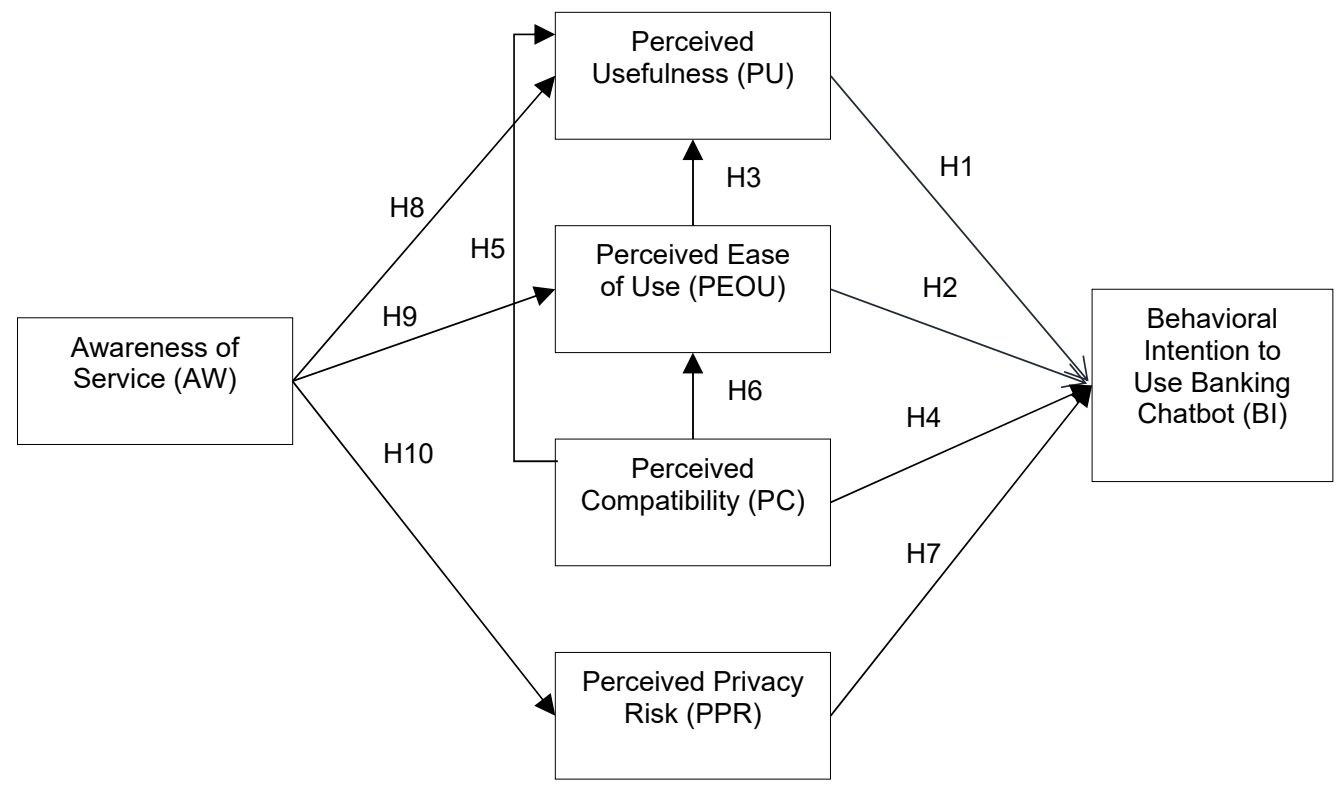

\subsection{Behavioral Intention to Use Banking Chatbot (BI)}

It was found that behavioral intention is a strong predictor of an individual's actual usage behavior (Venkatesh et al., 2003). BI is defined as "the strength of one's intention to perform a specified behavior" (Fishbein and Ajzen, 1975 p. 288). As banking chatbots are a relatively new type of technology, currently being in the phase of adoption, actual system usage would be difficult to measure. Thus, the present study will analyze customers' intention to use banking chatbots. In the banking technology adoption literature, perceived usefulness (Koenig-Lewis et al., 2010; Safeena et al., 2012; Martins et al., 2014; Alalwan et al., 2018; Farah et al., 2018), perceived ease of use ( Safeena et al., 2012; Martins et al., 2014; Alalwan et al., 2018; Farah et al., 2018), perceived compatibility (Kolodinsky et al., 2004; Koenig-Lewis et al., 2010), perceived privacy risk (Akturan and Tezcan, 2012; Giovanis et al., 2012; Arif et al., 2016; Shankar and Kumari, 2016), and awareness of the service (Sathye, 1999; Pikkarainen et al., 2004; Al-somali et al., 2009) were identified as predictors of behavior intention to use the technology.

\subsection{Perceived Usefulness (PU)}

Perceived usefulness is defined as "the degree to which a person believes that using a particular system would enhance his or her job performance" (Davis, 1989 p. 320). PU is considered to be similar to the performance expectancy construct in the UTAUT model (Li and Kishore, 2006), which was adopted and found to be a strong predictor of usage intention in several banking technology (e.g. m-banking i-banking and m-payment) adoption studies. Several studies on the adoption of 
m-banking (Koenig-Lewis et al., 2010; Safeena et al., 2012; Farah et al., 2018; Giovanis et al., 2019) and the adoption of i-banking (Martins et al., 2014; Alalwan et al., 2018) found that PU had a direct, positive effect on intention to use the studied technology. Moreover, Richad et al. (2019) found that perceived usefulness of the banking chatbot had significant effect on behavioral intention. Therefore, the first hypothesis is proposed:

H1: Perceived usefulness has a significant and positive effect on customers' intention to use banking chatbot.

\subsection{Perceived ease of use (PEOU)}

Perceived ease of use is defined as "the degree to which a person believes that using a particular system would be free from effort" (Davis, 1989 p. 320). PEOU is considered to be similar to the effort expectancy construct in the Unified Theory of Acceptance and Use of Technology (UTAUT) model (Li and Kishore, 2006), which was studied and found to be a strong predictor of usage intention in several banking technology (e.g. m-banking, i-banking and m-payment) adoption studies. First, existing literature on the adoption of m-banking (Safeena et al., 2012; Farah et al., 2018; Giovanis et al., 2019) and the adoption of i-banking (Alalwan et al., 2018; Martins et al., 2014) found that PEOU had a direct, positive effect on intention to use the studied technology. Second, studies showed that lower levels of effort expectations improved performance expectations of $\mathrm{m}$-banking (Akturan and Tezcan, 2012; Koenig-Lewis et al., 2010) and i-banking (Martins et al., 2014) activities. In addition (Richad et al., 2019) concluded that perceived ease of use of the banking chatbot had significant effect on behavioral intention. Therefore, the second and third hypotheses are proposed:

H2: Perceived ease of use has a significant and positive effect on customers' intention to use banking chatbot.

H3: Perceived ease of use has a significant and positive effect on perceived usefulness.

\subsection{Perceived compatibility (PC)}

Innovations that are compatible with the lifestyle of an individual, have a faster adoption rate (Rogers, 1983). Perceived compatibility is "the degree to which an innovation is perceived as consistent with the existing values, past experiences, and needs of potential adopters" (Rogers, 1983 p. 42). Several studies on m-banking (Koenig-Lewis et al., 2010; Giovanis et al., 2019;) and i-banking (Kolodinsky et al., 2004) adoption concluded that perceived compatibility had direct and positive effect on intention to use the certain technology. Moreover, some studies on m-banking (KoenigLewis et al., 2010) and i-banking (A. N. Giovanis et al., 2012) adoption found that perceived compatibility had a direct and positive effect on perceived usefulness, respectively on perceived ease of use. Thus, the fourth, fifth and sixth hypotheses are proposed:

H4: Perceived compatibility has a significant and positive effect on customers' intention to use banking chatbot. 
H5: Perceived compatibility has a significant and positive effect on perceived usefulness.

H6: Perceived compatibility has a significant and positive effect on perceived ease of use.

\subsection{Perceived Privacy Risk (PPR)}

Consumers tend to have concerns about the security and privacy of their financial information in online environments. Moreover, consumers are also concerned about the banks sharing their personal information with other companies (Kolodinsky et al., 2004). Perceived privacy risk refers to an individual's concern about potential loss of control over personal information, such as when information about an individual is used without that person's awareness (Akturan and Tezcan, 2012). Several studies on the acceptance of i-banking found that customers' perception of privacy risk (also referred as credibility) was an inhibitor of i-banking acceptance (A. N. Giovanis et al., 2012). Other studies on m-banking (Arif et al., 2016; Shankar and Kumari, 2016) adoption found that perceived privacy risk had a direct and negative effect on attitude toward the technology and on usage intention. Therefore, the seventh hypothesis is proposed:

H7: Perceived privacy risk has a direct and negative effect on customers' intention to use banking chatbot.

\subsection{Awareness of service (AW)}

Awareness of a new product or services is an important adoption factor of innovative technologies (Sathye, 1999). It was found that the amount of information that customers have about online banking, is a major factor influencing online banking adoption (Pikkarainen et al., 2004). Whereas, low awareness of online banking is a significant variable in causing people not to adopt online banking technology (Sathye, 1999). Al-somali et al. (2009) found that the awareness of online banking and its benefits had significant effects on the perceived usefulness and perceived ease of use of online banking acceptance. Furthermore, awareness of i-banking also decreased all aspects of perceived risk (Hanafizadeh and Khedmatgozar, 2012). Therefore, the eighth, ninth and tenth hypothesis are proposed:

H8: Awareness of service has a significant and positive effect on perceived usefulness.

H9: Awareness of service has a significant and positive effect on perceived ease of use.

H10: Awareness of service has a significant and negative effect on perceived privacy risk.

\section{Research method}

\subsection{Procedure}

The survey method was used to test the proposed research model based on a Romanian sample. Previous research is focused mostly on Asian countries, therefore data from an East Central European country will extend the actual literature. 
In Romania, there are 32 banks (Curs BNR, 2020) out of whom five institutions have implemented banking chatbots so far. Data were collected from April to May in 2020. It should be outlined that this was a pandemic period in Romania because of COVID-19. Therefore, the use of digital channels were highly recommended for all services. The questionnaire was distributed online through the Facebook platform. 307 questionnaires were collected. Data were assessed for multivariate outliers using a Mahalanobis Distance Test (Tabachnick and Fidell, 2007). Twenty multivariate outliers were identified and removed, the final sample contains 287 questionnaires. The present study follows a two-step approach to the analysis of the data obtained, including the assessment of measurement and structural models using the Partial Least Squares-Structural Equation Modeling (PLS-SEM) (Ringle et al., 2015).

\subsection{Measure items}

Measurement items used in this study were adapted from previously validated measures or developed on the basis of the literature review. Applying a forwardbackward method, the questionnaire was translated from English into Romanian. A five-point Likert scale ranging from totally disagree (1) to totally agree (5) was used in all statements. A pilot test of the measures was carried out on a sample of 5 randomly chosen people. Questionnaire statements were modified based on the results of the pilot test. The final questionnaire items that were used in order to measure each construct are presented in Table 2.

Table 2: Summary of measurement scales

\begin{tabular}{|c|c|c|c|}
\hline Constructs & & Measures & Source \\
\hline \multirow{4}{*}{$\begin{array}{l}\text { Perceived } \\
\text { usefulness } \\
\text { (PU) }\end{array}$} & PE1 & I find the banking chatbot useful in my daily life. & (Davis, 1989) \\
\hline & PE2 & $\begin{array}{l}\text { Using the banking chatbot increases my chances of } \\
\text { achieving things that are important to me. }\end{array}$ & $\begin{array}{l}\text { (Venkatesh } \\
\text { et al., 2003) }\end{array}$ \\
\hline & PE3 & $\begin{array}{l}\text { Using the banking chatbot helps me accomplish } \\
\text { things more quickly. }\end{array}$ & $\begin{array}{l}\text { (Venkatesh } \\
\text { et al., 2012) }\end{array}$ \\
\hline & PE4 & Using the banking chatbot increases my productivity. & \\
\hline \multirow{4}{*}{$\begin{array}{l}\text { Perceived } \\
\text { ease of use } \\
\text { (PEOU) }\end{array}$} & EE1 & Learning how to use the banking chatbot is easy for me. & (Davis, 1989) \\
\hline & EE2 & $\begin{array}{l}\text { My interaction with the banking chatbot is clear and } \\
\text { understandable. }\end{array}$ & $\begin{array}{l}\text { (Venkatesh } \\
\text { et al., 2003) }\end{array}$ \\
\hline & EE3 & I find the banking chatbot easy to use. & (Venkatesh \\
\hline & EE4 & $\begin{array}{l}\text { It is easy for me to become skillful at using the } \\
\text { banking chatbot. }\end{array}$ & et al., 2012) \\
\hline \multirow{4}{*}{$\begin{array}{l}\text { Perceived } \\
\text { compatibility } \\
\text { (PC) }\end{array}$} & PC1 & Using the banking chatbot fits well with my lifestyle. & (Moore and \\
\hline & PC2 & $\begin{array}{l}\text { Using the banking chatbot fits well with the way } \\
\text { I like to interact with companies. }\end{array}$ & $\begin{array}{l}\text { Benbasat, 1991) } \\
\text { (Schierz et al., }\end{array}$ \\
\hline & PC3 & I would appreciate using the banking chatbot instead & 2010) \\
\hline & & of alternative modes of customer service. & $\begin{array}{l}\text { (Yang et al., } \\
2012 \text { ) }\end{array}$ \\
\hline \multirow{2}{*}{$\begin{array}{l}\text { Perceived } \\
\text { privacy risk } \\
\text { (PPR) }\end{array}$} & PPR1 & $\begin{array}{l}\text { Privacy information could be misused, inappropriately } \\
\text { shared, or sold when using the banking chatbot. }\end{array}$ & $\begin{array}{l}\text { (Yang et al., } \\
2015)\end{array}$ \\
\hline & & $\begin{array}{l}\text { Personal information could be intercepted or } \\
\text { accessed when using the banking chatbot. }\end{array}$ & \\
\hline
\end{tabular}




\begin{tabular}{|c|c|c|c|}
\hline Constructs & & Measures & Source \\
\hline & $\begin{array}{l}\text { PPR3 } \\
\text { PPR4 }\end{array}$ & $\begin{array}{l}\text { Personal information could be collected, tracked, } \\
\text { and analyzed when using the banking chatbot. } \\
\text { Privacy could be exposed or accessed when using } \\
\text { the banking chatbot. }\end{array}$ & \\
\hline $\begin{array}{l}\text { Awareness } \\
\text { of service } \\
\text { (AW) }\end{array}$ & $\begin{array}{l}\text { AW1 } \\
\text { AW2 } \\
\text { AW3 } \\
\text { AW4 }\end{array}$ & $\begin{array}{l}\text { My bank has communicated a banking chatbot } \\
\text { usage policy to me. } \\
\text { My bank has a strategy regarding the usage of the } \\
\text { banking chatbot. } \\
\text { I have received sufficient information from my bank } \\
\text { regarding the usage of the banking chatbot. } \\
\text { I have received recommendations from my bank } \\
\text { on the use of the banking chatbot in the context of } \\
\text { the COVID-19 pandemic. }\end{array}$ & $\begin{array}{l}\text { (Al-somali et al., } \\
\text { 2009) } \\
\text { (Guesalaga, } \\
2016)\end{array}$ \\
\hline $\begin{array}{l}\text { Behavioral } \\
\text { intention to } \\
\text { use }(\mathrm{BI})\end{array}$ & $\begin{array}{l}\text { BI1 } \\
\text { BI2 } \\
\text { BI3 }\end{array}$ & $\begin{array}{l}\text { Given the opportunity, I will use the banking chatbot. } \\
\text { I am likely to use the banking chatbot in the near } \\
\text { future. } \\
\text { I am willing to use the banking chatbot in the near } \\
\text { future. } \\
\text { I intend to use the banking chatbot when the } \\
\text { opportunity arises. }\end{array}$ & $\begin{array}{l}\text { (Davis, 1989) } \\
\text { (Venkatesh and } \\
\text { Davis, 2000) } \\
\text { (Gefen et al., } \\
2003 \text { ) } \\
\text { (Schierz et al., } \\
\text { 2010) } \\
\end{array}$ \\
\hline
\end{tabular}

\section{Data analysis}

\subsection{Respondents' demographic profile}

Descriptive statistics were used to picture the demographic characteristics of the survey respondents. Table 3 illustrates the demographic profile of the respondents in terms of gender, age, education levels, occupation, field of work/study and residence.

Table 3: Demographic profile of survey sample

\begin{tabular}{lcc}
\hline Respondents characteristics & Frequency $\mathbf{( n = 2 8 7 )}$ & Percentage (\%) \\
\hline Gender & 114 & 39.7 \\
Male & 173 & 60.3 \\
Female & 287 & 100.0 \\
Total & & \\
\hline Age & 148 & 51.6 \\
24 and younger & 99 & 34.5 \\
$25-44$ & 40 & 13.9 \\
45 and older & 287 & 100.0 \\
Total & & \\
\hline Education & 88 & 30.7 \\
High school & 199 & 69.3 \\
Superior studies & 287 & 100.0 \\
Total & & \\
\hline
\end{tabular}




\begin{tabular}{lcc}
\hline Respondents characteristics & Frequency (n=287) & Percentage (\%) \\
\hline Occupation & 173 & 60.3 \\
Employed (including business owner, & 108 & 37.6 \\
freelancer) & 6 & 2.1 \\
Student & 287 & 100.0 \\
Other (unemployed, retired) & & \\
Total & 110 & 38.3 \\
\hline Field of work & & \\
Business (e.g. Accounting, Consulting, & 42 & 14.6 \\
Finance, HR, Marketing) & 97 & 33.8 \\
Engineering \& Computer Science (e.g. IT) & 38 & 13.2 \\
Services related activities (e.g. Hospitality) & 287 & 100 \\
Other & & \\
Total & 99 & 34.5 \\
\hline Residence & 129 & 44.9 \\
County seat & 59 & 20.6 \\
City & 287 & 100.0 \\
Village & & \\
Total & 3 & 1.0 \\
\hline Satisfaction with financial situation & 22 & 7.7 \\
(1) very dissatisfied & 127 & 44.3 \\
(2) dissatisfied & 106 & 36.9 \\
(3) neutral & 287 & 10.1 \\
(4) satisfied & & 100.0 \\
(5) very satisfied & & \\
Total & & \\
& & \\
\hline
\end{tabular}

Results show that the majority of respondents are female $(60.3 \%)$ and the largest proportion (51.6\%) of respondents by age groups, were those in the 24 years and younger category. $69.3 \%$ of respondents finished superior studies and $60.3 \%$ of respondents are employed, while $37.6 \%$ are students. In terms of field of work/study, the majority of the respondents work or study in the business field (38.3\%). The vast majority lives in county seats (34.5\%) and cities (44.9\%). Overall, $47 \%$ of survey respondents are either satisfied or very satisfied with their financial situation.

Table 4 summarizes the descriptive statistics for survey respondents in terms of chatbot usage. Respondents reported that m-banking (44.9\%) and ibanking $(34.9 \%)$ are the technologies that they are commonly using for banking purposes. Seventy respondents $(24.4 \%)$ stated that they have previously used a banking chatbot, while $75.6 \%$ of survey respondents haven't used such a system. The majority of those who have used banking chatbots, used it with a personal banking account $(80 \%)$ and $30 \%$ used it for the first time in the last six months. Finally, $47 \%$ of the respondents who have not used a banking chatbot before, stated that they are aware of the existence of the technology. 
Table 4: Descriptives of chatbot technology usage among respondents

\begin{tabular}{lcc}
\hline Respondents characteristics & Frequency & Percentage (\%) \\
\hline Usage of banking technologies & $\mathrm{n}=287$ & $30.9 \%$ \\
I-banking & 146 & $41.1 \%$ \\
M-banking & 194 & $19.9 \%$ \\
M-payment technology & 94 & $7.4 \%$ \\
Other & 35 & $0.6 \%$ \\
None & 3 & $100 \%$ \\
Total & 472 & \\
\hline Have used banking chatbot technology & $\mathrm{n}=287$ & 24.4 \\
Yes & 70 & 75.6 \\
No & 217 & 100.0 \\
Total & 287 & \\
\hline Use of chatbot for different types of & $\mathrm{n}=70$ & 80 \\
banking & & 5.7 \\
Personal account & 56 & 14.3 \\
Business account & 4 & 100 \\
Both & 10 & \\
Total & 70 & 100 \\
\hline First usage of a banking chatbot & $\mathrm{n}=70$ & 15.7 \\
This month & 7 & 30 \\
A month ago & 11 & 18.6 \\
6 months ago & 21 & 25.7 \\
A year ago & 13 & 100 \\
More than one year ago & 18 & 47.0 \\
Total & 70 & 40.6 \\
\hline Awareness of the banking chatbot & $\mathrm{n}=217$ & 12.4 \\
Yes & 102 & 100 \\
No & 88 & \\
Don't know & 27 & \\
Total & 217 & \\
& & \\
\hline
\end{tabular}

\subsection{Validation of the measurement scale}

The analysis of the data was carried out employing a two-phase approach in order to assess the reliability and validity of the measurement items using the Partial Least Squares-Structural Equation Modeling (PLS-SEM). The first phase consisted of the measurement model's analysis, while in the second step, structural relations between latent constructs were tested. The analysis of the measurement model involved the estimation of indicator reliability, internal consistency reliability, composite reliability, convergent validity and discriminant validity (Ringle et al., 2015).

Cronbach's Alpha and composite reliability (CR) were used to measure the reliability, while factor loadings (outer loadings) and Average Variance Extracted (AVE) were applied to measure the convergent validity. The results revealed that the questions measuring the constructs had reasonably acceptable reliability, and 
the measures of the latent variables had high levels of convergent validity. As shown in Table 5, the values of Cronbach's Alpha, composite reliability (CR) and factor loadings (outer loadings) were above the threshold value of 0.7 , the values of Average Variance Extracted (AVE) were all above the recommended value of 0.5 , respectively.

Table 5: Psychometric properties of the constructs

\begin{tabular}{|c|c|c|c|c|c|c|}
\hline Construct & Indicator & $\begin{array}{c}\text { Outer } \\
\text { Weights }\end{array}$ & $\begin{array}{l}\text { Outer } \\
\text { Loadings }\end{array}$ & $\begin{array}{c}\text { Cronbach's } \\
\alpha \\
\end{array}$ & CR & AVE \\
\hline Awareness of service (AW) & $\begin{array}{l}\text { AW } 1 \\
\text { AW } 2 \\
\text { AW } 3 \\
\text { AW } 4\end{array}$ & $\begin{array}{l}0.299 \\
0.307 \\
0.289 \\
0.242 \\
\end{array}$ & $\begin{array}{l}0.914 \\
0.822 \\
0.921 \\
0.858 \\
\end{array}$ & 0.902 & 0.907 & 0.932 \\
\hline Perceived usefulness (PU) & $\begin{array}{l}\text { PE } 1 \\
\text { PE } 2 \\
\text { PE } 3 \\
\text { PE } 4 \\
\end{array}$ & $\begin{array}{r}0.26 \\
0.283 \\
0.273 \\
0.286 \\
\end{array}$ & $\begin{array}{r}0.89 \\
0.901 \\
0.906 \\
0.931 \\
\end{array}$ & 0.928 & 0.929 & 0.949 \\
\hline $\begin{array}{l}\text { Perceived ease of use } \\
\text { (PEOU) }\end{array}$ & $\begin{array}{l}\text { EE 1 } \\
\text { EE } 2 \\
\text { EE } 3 \\
\text { EE 4 } \\
\end{array}$ & $\begin{array}{l}0.259 \\
0.289 \\
0.275 \\
0.273 \\
\end{array}$ & $\begin{array}{r}0.902 \\
0.921 \\
0.926 \\
0.9 \\
\end{array}$ & 0.933 & 0.934 & 0.952 \\
\hline $\begin{array}{l}\text { Perceived Compatibility } \\
\text { (PC) }\end{array}$ & $\begin{array}{l}\mathrm{PC} 1 \\
\mathrm{PC} 2 \\
\mathrm{PC} 3\end{array}$ & $\begin{array}{l}0.394 \\
0.385 \\
0.342 \\
\end{array}$ & $\begin{array}{l}0.887 \\
0.916 \\
0.871\end{array}$ & 0.871 & 0.876 & 0.921 \\
\hline $\begin{array}{l}\text { Perceived privacy risk } \\
\text { (PPR) }\end{array}$ & $\begin{array}{l}\text { PPR } 1 \\
\text { PPR } 2 \\
\text { PPR } 3 \\
\text { PPR } 4\end{array}$ & $\begin{array}{l}0.288 \\
0.244 \\
0.232 \\
0.379 \\
\end{array}$ & $\begin{array}{l}0.857 \\
0.896 \\
0.814 \\
0.912 \\
\end{array}$ & 0.894 & 0.935 & 0.926 \\
\hline $\begin{array}{l}\text { Behavioral intention to use } \\
\text { Banking Chatbot (BI) }\end{array}$ & $\begin{array}{l}\mathrm{BI} 1 \\
\mathrm{BI} 2 \\
\mathrm{BI} 3 \\
\mathrm{BI} 4\end{array}$ & $\begin{array}{l}0.301 \\
0.264 \\
0.269 \\
0.272\end{array}$ & $\begin{array}{l}0.916 \\
0.908 \\
0.892 \\
0.901\end{array}$ & 0.926 & 0.928 & 0.947 \\
\hline
\end{tabular}

It has been found that the "Heterotrait-Monotrait ratio (HTMT)" is a significant measure for testing the discriminant validity (Henseler et al., 2015). As shown in Table 6 , all the HTMT ratio values were below the suggested value of 0.85 , which indicated that all the items satisfied the criteria for good discriminant validity. Thus, the measurement model is verified, and the evaluation of the structural model can be carried out.

In order to confirm and validate the measurement instruments and to define the relationships between observed and unobserved variables, a measurement model consisting of six constructs has been established. Results showed that the fitted 
measurement model provided a fairly reasonable fit, the value of NFI being 0.874 , which is greater than the threshold value of 0.8 for the model to be considered good (Forza and Filippini, 1998), while the value of SRMR being 0.049 (Hair et al., 2017).

Table 6: Discriminant validity of constructs - Heterotrait-Monotrait Ratio (HTMT)

\begin{tabular}{lrrrrrr}
\hline & PEOU & AW & BI & PC & PPR & PU \\
\hline PEOU & & & & & & \\
AW & 0.403 & & & & & \\
BI & 0.479 & 0.331 & & & & \\
PC & 0.546 & 0.33 & 0.74 & & & \\
PPR & 0.17 & 0.19 & 0.172 & 0.109 & & \\
PU & 0.546 & 0.41 & 0.623 & 0.782 & 0.109 & \\
\hline
\end{tabular}

\subsection{Examination of research hypotheses}

The structural model was evaluated by examining the path coefficients beta weight $(\beta)$ and coefficient of determination $\left(R^{2}\right)$. The $\beta$ value indicates the strength of the relationships between the dependent and independent variables, while the $R^{2}$ value describes the variance explained by independent variables which can be interpreted as the predictive power of the model. The evaluation of the research hypothesis can be seen in Table 7, while Figure 2 shows the statistical analysis' results of the research model.

Results indicate that seven variables have significant statistical support. First, awareness of service is correlated significantly and positively with perceived usefulness $(\beta=0.143 ; p \leq 0.001)$ and perceived ease of use $(\beta=0.25 ; p \leq 0.001)$, and it has a significant and negative effect on perceived privacy risk $(\beta=-0.173$; $p \leq 0.05)$. Second, perceived ease of use has significant and positive effect on perceived usefulness $(\beta=0.168 ; p \leq 0.001)$. Perceived compatibility has significant and positive effect on both perceived usefulness $(\beta=0.581 ; p \leq 0.001)$ and perceived ease of use $(\beta=0.421 ; p \leq 0.001)$. Last, intention to use is significantly and positively influenced by perceived usefulness $(\beta=0.176 ; p \leq 0.05)$ and perceived compatibility $(\beta=0.484 ; p \leq 0.001)$. Also, results indicate that perceived ease of use and perceived privacy risk are not correlated with intention to use. Therefore, $\mathrm{H} 1, \mathrm{H} 3, \mathrm{H} 4, \mathrm{H} 5, \mathrm{H} 6, \mathrm{H} 8, \mathrm{H} 9$ and $\mathrm{H} 10$ were supported by the empirical data, while $\mathrm{H} 2$ and $\mathrm{H} 7$ were rejected.

Table 7: Assessment of the structural model

\begin{tabular}{llcrrrr}
\hline No. & $\begin{array}{c}\text { Hypothesis } \\
\text { path }\end{array}$ & $\begin{array}{c}\text { Path } \\
\text { coefficient }(\boldsymbol{\beta})\end{array}$ & STDEV & t-Value & $\boldsymbol{p}$-Value & Supported? \\
\hline $\mathrm{H} 1$ & $\mathrm{PU} \rightarrow \mathrm{BI}$ & 0.176 & 0.068 & 2.601 & $0.010^{*}$ & yes \\
$\mathrm{H} 2$ & $\mathrm{PEOU} \rightarrow \mathrm{BI}$ & 0.104 & 0.055 & 1.909 & $0.057^{\text {ns }}$ & no \\
$\mathrm{H} 3$ & $\mathrm{PEOU} \rightarrow \mathrm{PU}$ & 0.168 & 0.052 & 3.23 & $0.001^{*}$ & yes \\
$\mathrm{H} 4$ & $\mathrm{PC} \rightarrow \mathrm{BI}$ & 0.484 & 0.06 & 8.116 & $0.000^{* *}$ & yes \\
$\mathrm{H} 5$ & $\mathrm{PC} \rightarrow \mathrm{PU}$ & 0.581 & 0.047 & 12.451 & $0.000^{* *}$ & yes
\end{tabular}




\begin{tabular}{llcrrrr}
\hline No. & $\begin{array}{c}\text { Hypothesis } \\
\text { path }\end{array}$ & $\begin{array}{c}\text { Path } \\
\text { coefficient }(\boldsymbol{\beta})\end{array}$ & STDEV & t-Value & $\boldsymbol{p}$-Value & Supported? \\
\hline $\mathrm{H} 6$ & $\mathrm{PC} \rightarrow \mathrm{PEOU}$ & 0.421 & 0.054 & 7.807 & $0.000^{* *}$ & yes \\
$\mathrm{H} 7$ & $\mathrm{PPR} \rightarrow \mathrm{BI}$ & -0.082 & 0.045 & 1.81 & $0.071^{\text {ns }}$ & no \\
$\mathrm{H} 8$ & $\mathrm{AW} \rightarrow \mathrm{PU}$ & 0.143 & 0.038 & 3.763 & $0.000^{* *}$ & yes \\
$\mathrm{H} 9$ & $\mathrm{AW} \rightarrow \mathrm{PEOU}$ & 0.25 & 0.051 & 4.896 & $0.000^{* *}$ & yes \\
$\mathrm{H} 10$ & $\mathrm{AW} \rightarrow \mathrm{PPR}$ & -0.173 & 0.066 & 2.63 & $0.009^{*}$ & yes \\
\hline
\end{tabular}

Note: *Significance at $p<0.05) ;{ }^{* *}(p<0.001) ;{ }^{n s}$ Not significant

The results show that awareness of service, perceived ease of use and perceived compatibility together explain $55 \%$ of the variance in perceived usefulness. Moreover, awareness of service and perceived compatibility together explain $30.3 \%$ of the variance in perceived ease of use. Also, awareness of services explains $3 \%$ of the variance in perceived privacy risk. Finally, perceived usefulness and perceived compatibility together explain $48.5 \%$ of the variance in behavioral intention.

Figure 2. Proposed research model for attitude toward banking chatbots

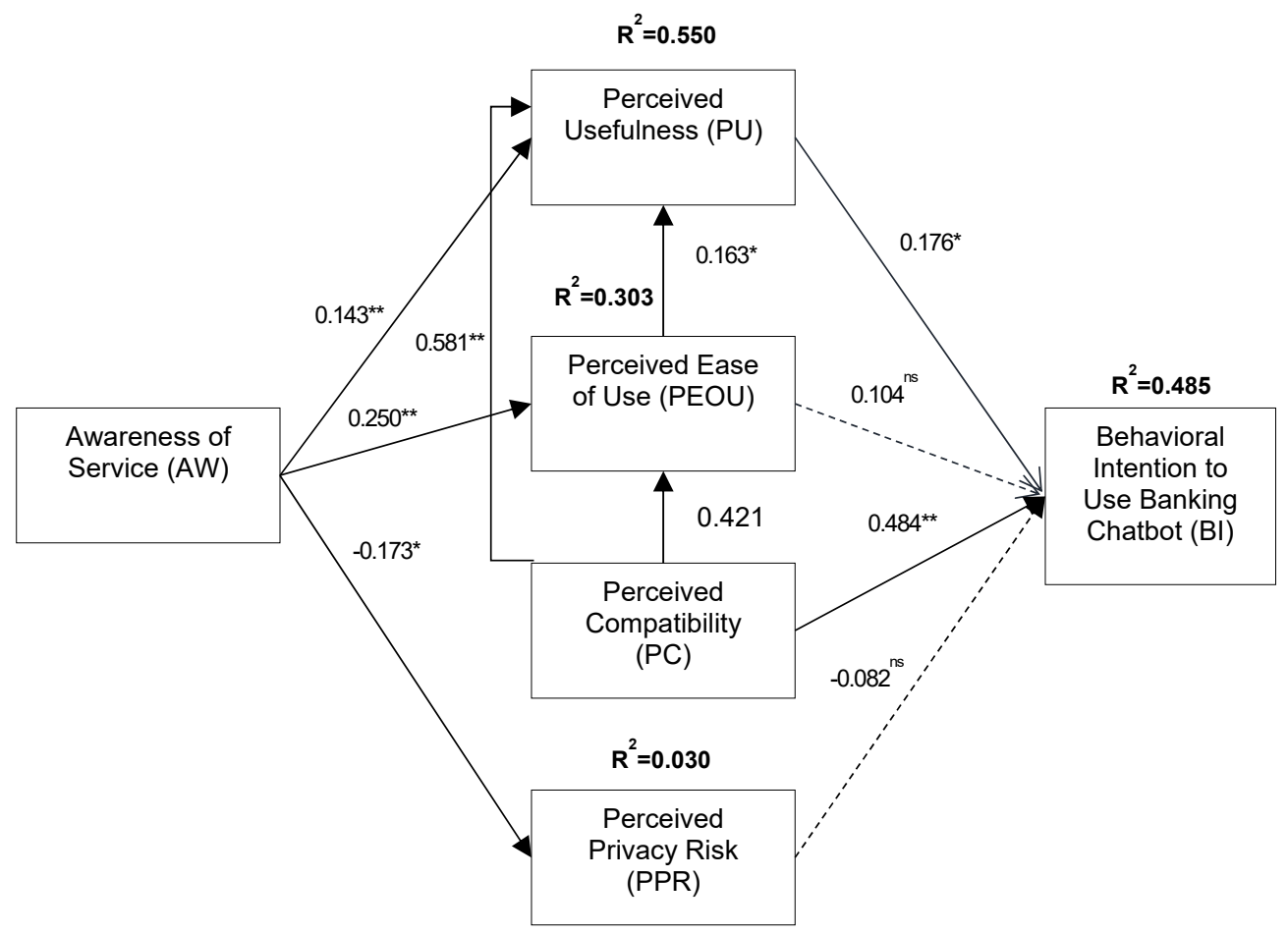

Note: * $(p<0.05) ;{ }^{* *}(p<0.001) ;{ }^{n s}$ and dashed arrows (paths coefficients that are not statistically significant) 


\section{Discussion}

Artificial intelligence based chatbot applications have become a very popular form automatizing customer service processes in the financial sector, transforming communication between banks and consumers. Many banks have implemented chatbots in order to reduce costs and to improve services quality. Thus, it is essential for these institutions to identify factors that influence customer adoption of this technology.

The present study identified two factors that significantly impact customers' intention to use banking chatbots in the Romanian banking industry including, perceived usefulness and perceived compatibility. Moreover, the proposed research model explained $48.5 \%$ of the behavioral intention to use banking chatbots, the value being higher than that of $40 \%$ found in several studies that adopted TAM (Venkatesh and Davis, 2000).

Among the two identified factors, perceived compatibility has the strongest effect on customers' intention to use banking chatbots which is consistent with earlier findings of i-banking (A. N. Giovanis et al., 2012) and m-banking (KoenigLewis et al., 2010) adoption research. The results indicate that the higher is consumers' perception of the banking chatbot being compatible with their lifestyle, the higher their willingness is to adopt the technology. This indicates that it is important to develop and implement banking chatbots in a way that is compatible with the lifestyle and values of the bank's customers. Moreover, the findings of this study indicate that perceived compatibility also has an indirect and significant effect on intention to use chatbots through perceived usefulness and perceived ease of use, meaning that compatibility leads consumers to perceive banking chatbots as being more useful and easier to use. These findings are in line with previous research on i-banking (A. N. Giovanis et al., 2012) andm-banking (Koenig-Lewis et al., 2010) adoption.

Perceived usefulness was also found to be an important antecedent of customers' behavioral intention to use banking chatbots. These findings support observation of previous research into i-banking (Martins et al., 2014) and mbanking (Farah et al., 2018; Koenig-Lewis et al., 2010; Safeena et al., 2012) adoption. Consumers perception of the banking chatbot being useful and representing a quicker and easier way to manage their finances, leads to a higher level of intention to use the banking chatbot.

The effect of perceived ease of use on behavioral intention is disputable in banking technology adoption research. Several studies on i-banking (Alalwan et al., 2018; Martins et al., 2014) andm-banking (Safeena et al., 2012; Farah et al., 2018) adoption found that perceived ease of use significantly and positively influenced usage intention, whereas other studies on i-banking (Pikkarainen et al., 2004) and m-banking (Koenig-Lewis et al., 2010) adoption found no significant results in this regard. The findings of the current study are consistent with the findings of Pikkarainen et al. (2004) on i-banking and the results of Koenig-Lewis et al. (2010) on m-banking who found that perceived ease of use had no significant effect on usage intention. Moreover, the results of the current study indicate that perceived ease of use has a significant indirect effect on behavioral intention to use banking chatbots through perceived usefulness. Several studies found that perceived ease of use has less impact on technology acceptance than perceived 
usefulness (Davis, 1989; Venkatesh and Davis, 2000) since perceived ease of use influences technology acceptance through perceived usefulness (Pikkarainen et al., 2004).

Contrary to previous expectations, perceived privacy risk had no significant effect on behavioral intention to use banking chatbots. Even though several studies on the acceptance of i-banking (Giovanis et al., 2012) and m-banking adoption concluded that perceived privacy risk had a direct and negative effect on intention to use (Arif et al., 2016; Shankar and Kumari, 2016), the present study did not find significant relationship in this regard. These results are in line with the findings of Akturan and Tezcan (2012) on m-banking adoption who concluded that perceived privacy risk had no significant effect on usage intention. That lack of evidence on this matter has two explanations. First, in i-banking adoption studies, the dimensions of the perceived risk factor are classified into six groups including, time, financial, performance, social, security, and privacy risks (Hanafizadeh and Khedmatgozar, 2012). According to Aldás-Manzano et al. (2009), not all the risk dimensions are relevant in the context of online banking services. The results of the current study indicate that perceived privacy risk is a risk dimension that is not applicable in banking chatbot adoption. Second, the sample of the current research consisted predominantly of individuals aged 24 or younger with a higher education degree. This age and educational demographic generally has considerable experience of online banking, mobile phone usage and other internet-related activities (Akturan and Tezcan, 2012). Thus, the non-significant relation between perceived privacy risk and behavioral intention can be explained by the age of the respondents of the current study.

Regarding the indirect relationships between the studied constructs, it was found that awareness of the service has an indirect effect on behavioral intention through perceived usefulness. Consistent with the results of Al-somali et al. (2009) on online banking adoption, the more information consumers have about the service, the more useful they find it. Moreover, awareness of the service also has significant and positive effect on perceived ease of use, and significant and negative effect on perceived privacy risk which is in line with the findings of Al-somali et al. (2009) and Hanafizadeh and Khedmatgozar (2012) on online banking. Therefore, high awareness of banking chatbots is a critical factor in banking chatbot adoption.

\subsection{Theoretical implications}

Results of the current study offer useful insights for academic perspective. First, the present analysis extended technology adoption research to the area of banking chatbot technology with the following variables: perceived usefulness, perceived ease of use, compatibility, privacy risk and awareness. Compatibility and awareness are innovative factors in studying chatbot adoption. Overall, $48.5 \%$ of the variance of behavioral intention to use banking chatbots is explained by the proposed conceptual model. Perceived compatibility and perceived usefulness were identified as factors that have direct effect on banking chatbot adoption. Second, results highlight the importance of awareness of service in the context of banking chatbot adoption as the construct has an indirect effect on usage intention through perceived usefulness. Even if this study did not find evidence for the effect of perceived ease of use and perceived privacy risk on behavioral intention, it is 
unequivocal that awareness has direct effects on these two variables as well. These results emphasize the importance of awareness of the service and its benefits in the context of technology adoption in the banking industry. Thus, the current study was able to contribute to existing literature on technology adoption in the banking industry, and in the field of chatbot technology adoption.

\subsection{Managerial implications}

There are several managerial implications of this study for the banking sector. First, significant effects of perceived compatibility and perceived usefulness on behavioral intention indicate that consumers expect banking chatbots to be compatible with their lifestyle and to provide benefits for them. Therefore, communication campaigns should contain this type of information. Second, the role of awareness of the services has indirect effect on usage intentions, which indicate the importance of informing consumers about the existence and benefits of using the banking chatbots. Thus, banks and developers of banking chatbot applications should devote great effort to the factors of utility and compatibility when designing, implementing and upgrading such systems. Moreover, marketing campaigns that emphasize the usefulness and benefits of banking chatbots, namely $24 / 7$ availability of the service, high convenience, ease of use, and the time and cost saving aspect of the application, may attract consumers' attention and could drive the acceptance and use of the technology. As awareness of the service, its features and its benefits could be a key factor is banking chatbot adoption, banks should focus on providing information about the system and communication with consumers in order to encourage the adoption.

\subsection{Limitations and future research directions}

While the current study adds to the existing literature, its limitations should be acknowledged. First, the questionnaire respondents were mainly young, highly educated individuals whose actions may vary somewhat from the population average. Thus, the study sample is not representative and the findings are not generalizable. Second, this research is not specific to a single banking chatbot application or specific bank. Future research should investigate specific banking chatbot systems as these systems could have unique service features depending on the banks that have implemented them. There could be specific variables that are unique for each chatbot, and other adoption factors that have significant impact on adoption, such as relative advantage, which was not investigated, however, future research is encouraged to fill this gap. Future research also needs to investigate the proposed research model in a different geographic location with special emphasis on rural areas and the model should be tested on a different sample.

\section{Conclusion}

The adoption of technologies applied in the banking industry are widely studied in the literature. However, a more and more popular and frequently implemented technology, namely chatbot technology in the context of the banking industry, has 
received limited attention. To address this research gap, the present study was conducted with the aim of identifying the main factors that influence customers' intention to use the banking chatbot technology. The proposed research model was built by adopting concepts from the TAM model, extending it with compatibility, customers' perceived privacy risk and awareness of the service. Data for the present analysis was collected from 287 consumers via online, applying a self-administrated survey method. The findings supported the conceptual model by predicting $48.5 \%$ of variance in the behavioral intention. Perceived usefulness and perceived compatibility significantly predicted the customers' intention to use the banking chatbot. Awareness of the service had an effect on perceived ease of use, perceived privacy risk, and it indirectly affected usage intention through perceived usefulness. Also, perceived ease of use influenced perceived usefulness, and perceived compatibility had an effect on both perceived ease of use and perceived usefulness. Yet, perceived ease of use and perceived privacy risk were not found to be significant determinants of behavioral intention. As a result, the current study was able to make a significant contribution to the field for both academics and practitioners.

\section{Acknowledgements}

The data collection of this research was supported by the Babeș-Bolyai University Institute of Advanced Studies in Science and Technology (STAR-UBB Institute).

\section{References}

Akturan, U., Tezcan, N. (2012). Mobile banking adoption of the youth market: Perceptions and intentions. Marketing Intelligence and Planning, 30(4).

Al-somali, S. A., Gholami, R., Clegg, B. (2009). An investigation into the acceptance of online banking in Saudi Arabia. Technovation, 29(2), 130-141.

Alalwan, A. A., Dwivedi, Y. K., Rana, N. P., Algharabat, R. (2018). Examining factors influencing Jordanian customers' intentions and adoption of internet banking: Extending UTAUT2 with risk. Journal of Retailing and Consumer Services, 40.

Almahri, F. A. J., Bell, D., Merhi, M. (2020). Understanding Student Acceptance and Use of Chatbots in the United Kingdom Universities: A Structural Equation Modelling Approach. 6th International Conference on Information Management (ICIM), 284-288.

Arif, I., Afshan, S., Sharif, A. (2016). Resistance to Mobile Banking Adoption in a Developing Country: Evidence from Modified TAM. Journal of Finance and Economics Research, 1(1), 25-42.

Bala, K., Kumar, M., Hulawale, S., Pandita, S. (2017). Chat-bot for college management system using Al. International Research Journal of Engineering and Technology, $4(11)$.

Business Insider. (2021, January 13). Artificial Intelligence in Banking 2021: How Banks Use Al. https://www.businessinsider.com/ai-in-banking-report 
Cardona, R. D., Werth, O., Schönborn, S., Breitner, M. H. (2019). A Mixed Methods Analysis of the Adoption and Diffusion of Chatbot Technology in the German Insurance Sector A. 25th Americas Conference on Information Systems (AMCIS), January.

Curs BNR. (2020). Lista bancilor din Romania . https://www.cursbnr.ro/lista-banci

Davis, F. (1989). Perceived usefulness, perceived ease of use, and user acceptance of information technology. MIS Quarterly, 13(3), 319-340.

Farah, M. F., Hasni, M. J. S., Abbas, A. K. (2018). Mobile-banking adoption: empirical evidence from the banking sector in Pakistan. International Journal of Bank Marketing, 36(7).

Fishbein, M., Ajzen, I. (1975). Belief, Attitude, Intention, and Behavior: An Introduction to Theory and Research. Addison-Wesley.

Forza, C., Filippini, R. (1998). TQM impact on quality conformance and customer satisfaction: A causal model. International Journal of Production Economics, 55(1).

Gefen, D., Karahanna, E., Straub, D. W. (2003). Trust and tam in online shopping: AN integrated model. MIS Quarterly: Management Information Systems, 27(1).

Giovanis, A., Athanasopoulou, P., Assimakopoulos, C., Sarmaniotis, C. (2019). Adoption of mobile banking services: A comparative analysis of four competing theoretical models. International Journal of Bank Marketing, 37(5), 11651189.

Giovanis, A. N., Binioris, S., Polychronopoulos, G. (2012). An extension of TAM model with IDT and security/privacy risk in the adoption of internet banking services in Greece. EuroMed Journal of Business, 7(1), 24-53.

Guesalaga, R. (2016). The use of social media in sales: Individual and organizational antecedents, and the role of customer engagement in social media. Industrial Marketing Management, 54, 71-79.

Gupta, A., Sharma, D. (2019). Customers' Attitude towards Chatbots in Banking Industry of India. International Journal of Innovative Technology and Exploring Engineering, 8(11).

Hair, J. F., Hult, G. T. M., Ringle, C. M., Sarstedt, M. (2017). A Primer on Partial Least Squares Structural Equation Modeling (PLS-SEM). Second Edition. In California: Sage.

Hanafizadeh, P., Khedmatgozar, H. R. (2012). The mediating role of the dimensions of the perceived risk in the effect of customers' awareness on the adoption of Internet banking in Iran. Electronic Commerce Research, 12(2).

Henseler, J., Ringle, C. M., Sarstedt, M. (2015). A new criterion for assessing discriminant validity in variance-based structural equation modeling. Journal of the Academy of Marketing Science, 43(1).

Juniper Research. (2020). Chatbots, a Game Changer for Banking \& Healthcare. https://www.juniperresearch.com/press/press-releases/chatbots-a-gamechanger-for-banking-healthcare

Koenig-Lewis, N., Palmer, A., Moll, A. (2010). Predicting young consumers' take up of mobile banking services. International Journal of Bank Marketing, 28(5).

Kolodinsky, J. M., Hogarth, J. M., Hilgert, M. A. (2004). The adoption of electronic banking technologies by US consumers. International Journal of Bank Marketing, 22(4). 
Laumer, S., Maier, C., Fabian, G. (2020). Chatbot acceptance in healthcare: Explaining user adoption of conversational agents for disease diagnosis. 27th European Conference on Information Systems - Information Systems for a Sharing Society, ECIS 2019.

Li, J. P., Kishore, R. (2006). How robust is the UTAUT instrument? A multigroup invariance analysis in the context of acceptance and use of online community weblog systems. SIGMIS CPR'06 - Proceedings of the 2006 ACM SIGMIS CPR Conference, 2006.

Martins, C., Oliveira, T., Popovič, A. (2014). Understanding the internet banking adoption: A unified theory of acceptance and use of technology and perceived risk application. International Journal of Information Management, 34(1).

McKinsey. (2020). Digital adoption through COVID-19 and beyond | McKinsey. https://www.mckinsey.com/business-functions/mckinsey-digital/ourinsights/the-covid-19-recovery-will-be-digital-a-plan-for-the-first-90-days

Melián-González, S., Gutiérrez-Taño, D., Bulchand-Gidumal, J. (2021). Predicting the intentions to use chatbots for travel and tourism. Current Issues in Tourism, 24(2), 192-210.

Moldovan, I.-Z., Săplăcan, Z. (2018). What makes Romanians to bank on their smarthphones? Determinants of mobile banking adoption. Studia UBB Negotia, LXIII(1), 5-33. https://econpapers.repec.org/RePEc:bbn:journl: 2018_1_1_moldovan

Moore, C. G., Benbasat, I. (1991). Development of an Instrument to Measure the Perceptions of Adopting an Information Technology Innovation. In Information Systems Research (Vol. 2, Issue 3, pp. 192-222).

Mordor Intelligence. (2019). Chatbot Market - Growth, Trends, COVID-19 Impact, and Forecasts (2021 - 2026). https://www.mordorintelligence.com/industryreports/chatbot-market

Nguyen, Q. N., Sidorova, A. (2017). Al capabilities and user experiences: a comparative study of user reviews for assistant and non-assistant mobile apps. AMCIS 2017 - America's Conference on Information Systems: A Tradition of Innovation, 2017-August, 1-10.

Pikkarainen, T., Pikkarainen, K., Karjaluoto, H., Pahnila, S. (2004). Consumer acceptance of online banking: An extension of the technology acceptance model. In Internet Research (Vol. 14, Issue 3).

Quah, J. T. S., Chua, Y. W. (2019). Chatbot assisted marketing in financial service industry. Lecture Notes in Computer Science (Including Subseries Lecture Notes in Artificial Intelligence and Lecture Notes in Bioinformatics), 11515 LNCS.

Richad, R., Vivensius, V., Sfenrianto, S., Kaburuan, E. R. (2019). Analysis of factors influencing millennial's technology acceptance of chatbot in the banking industry in Indonesia. International Journal of Civil Engineering and Technology, 10(4), 1270-1281.

Ringle, C. M., Wende, S., Becker, J.-M. (2015). SmartPLS 3. Bönningstedt: SmartPLS. Retrieved From.

Rogers, E. M. (1983). Difiusion of innovations. New York: Free Press.

Safeena, R., Date, H., Kammani, A., Hundewale, N. (2012). Technology Adoption and Indian Consumers: Study on Mobile Banking. International Journal of Computer Theory and Engineering. 
Sarbabidya, S., Saha, T. (2020). Role of Chatbot in Customer Service: A Study from the Perspectives of the Banking Industry of Bangladesh. International Review of Business Research Papers, 16(1).

Sathye, M. (1999). Adoption of Internet banking by Australian consumers: an empirical investigation. International Journal of Bank Marketing, 17(7), 324-334.

Schierz, P. G., Schilke, O., Wirtz, B. W. (2010). Understanding consumer acceptance of mobile payment services: An empirical analysis. Electronic Commerce Research and Applications, 9(3). https://doi.org/10.1016/j.elerap. 2009.07.005

Shaikh, A. A., Karjaluoto, H. (2015). Telematics and Informatics Mobile banking adoption: A literature review. In Telematics and Informatics (Vol. 32, Issue 1, pp. 129-142). Elsevier Ltd.

Shankar, A., Kumari, P. (2016). Journal of Internet Banking and Commerce Factors Affecting Mobile Banking Adoption Behavior in India. Journal of Internet Banking and Commerce, 21(1).

Tabachnick, B. G., Fidell, L. S. (2007). Using Multivariate Statistics. In Boston: Pearson Allyn and Bacon (5th ed.). MA: Pearson.

Tarbal, J. (2020). Chatbots in Financial Services: Benefits, Use Cases \& Key Features | 2020. https://www.artificial-solutions.com/blog/chatbots-financialservices-benefits-use-cases

Trivedi, J. (2019). Examining the Customer Experience of Using Banking Chatbots and Its Impact on Brand Love: The Moderating Role of Perceived Risk. Journal of Internet Commerce, 18(1).

Venkatesh, Thong, Xu. (2012). Consumer Acceptance and Use of Information Technology: Extending the Unified Theory of Acceptance and Use of Technology. MIS Quarterly, 36(1).

Venkatesh, V., Davis, F. D. (2000). Theoretical extension of the Technology Acceptance Model: Four longitudinal field studies. Management Science, 46(2).

Venkatesh, V., Morris, M. G., Davis, G. B., Davis, F. D. (2003). User acceptance of information technology: Toward a unified view. MIS Quarterly: Management Information Systems, 27(3).

Vieira, A., Sehgal, A. (2017). How banks can better serve their customers through artificial techniques. In Digital Marketplaces Unleashed.

Yang, S., Lu, Y., Gupta, S., Cao, Y., Zhang, R. (2012). Mobile payment services adoption across time: An empirical study of the effects of behavioral beliefs, social influences, and personal traits. Computers in Human Behavior, 28(1).

Yang, Y., Liu, Y., Li, H., Yu, B. (2015). Understanding perceived risks in mobile payment acceptance. Industrial Management \& Data Systems, 115(2), 253269.

Yousafzai, S. Y. (2012). A literature review of theoretical models of Internet banking adoption at the individual level. In Journal of Financial Services Marketing (Vol. 17, Issue 3, pp. 215-226). 